Januar 6 is $\alpha=6 \mathrm{~h} . \quad 18 \cdot 5 \mathrm{~m} ., \delta=+53^{\circ} 48 \cdot \mathrm{I}^{\prime}$, and it is stitl inoving northward slowly.

Solar Activity and Magnetic Storms.-No. I, vol. 1xx., of the Monthly Notices (November, 1909) contains three papers on the connection between solar activity and magnetic storms.

In the first, Dr. W. J. S. Lockyer discusses a series of spectroheliograms taken at the Solar Physics Observatory, South Kensington, and shows that the enormous magnetic disturbance of September 25, 1909, was preceded by an abnormal outburst in connection with a spot then on the sun. One of these photographs shows that at about ro a.m., September 24, the calcium flocculus surrounding the spot was so disturbed as to obliterate the very fine nuclei seen on the preceding photographs; these nuclei reappeared on a negative taken at IIh. IIm. the same morning.

The time of the maximum magnetic disturbance appears to have been 4 h. $30 \mathrm{~m}$. p.m. on September 25, showing a "lag," after the solar disturbance, of about 30.5 hours. In a similar case, in 1892 , Prof. Hale found that the "lag " was about $25 \cdot 3$ hours.

In the second paper, Father Cortie deals generally with the recent solar and magnetic disturbances, and points out that this spot was not accompanied by any abnormal, visual, spectroscopic outburst commensurable in intensity with the magnetic disturbance.

In the last paper Mr. Michie Smith shows, from the evidence of the spectroheliograms and magnetograms secured at the Kodaikánal Observatory, that a great eruption about a spot photographed on September 28, 1909, was accompanied by a magnetic disturbance.

Star Swarms.-In an article which appears in the current Fortnightly Review (p. 140), Prof. Turner gives a very interesting and lucid popular account of "Migrating Stars."

The difficulties and results of Prof. Boss's work in showing that a number of stars in Taurus are moving together, apparently to a convergent but really along parallel paths, are clearly explained and illustrated by some attractive analogies. This cluster is now some $\mathrm{I} 20$ light-years from us, and occupies a space on the celestial globe comparable with that occupied by India on the terrestrial; but in about 65 million years it will have receded so far as to appear merely as a star cluster, occupying an area, using the same analogy, about equal to Anglesea.

The researches of Dr. Ludendorff on the related stars of Ursa Major, and of Dr. Hertzsprung, who has added Sirius, a Coronæ, and other stars to it, are also described.

In No, 4366 of the Astronomische Nachrichten, Herr Kostinsky directs attention to two swarms of stars in the neighbourhood of the star clusters $\chi$ and $h$ Persei, the individual members of which appear to partake of motions in a common direction.

A Large Nebula in Cetus.--On a plate taken in the autumn by Herr Lorenz, Prof. Wolf found traces of a large patch of nebulous matter in the constellation Cetus, and has recently succeeded in photographing it with the Waltz reflector. The negative obtained, with two hours' exposure, shows that the object is a long streak running in the $\mathrm{N}$. and $\mathrm{S}$. direction, its length being $\mathrm{I}_{5}^{\prime}$; at the broadest part, E. and $W$., its breadth is $3^{\prime}$. The position of the central part of the nebula is $\alpha=23 \mathrm{~h}$. $54.6 \mathrm{~m}$., $\delta=-16^{\circ} 15^{\prime}\left(1855^{\circ}\right)$, and the whole is seen to be a conslomeration of smaller nebulæ (Astronomische Nachrichten, No. 4380 , December 28,1909 , p. 187).

AnNuaire astronomigue et météorologigue, igio.For the amateur observer conversant with French, there are few more useful volumes than M. Flammarion's "Annuaire." This year's issue is very similar to its predecessors, but contains a useful resumé, with many drawings, of the observations of Mars during the recent opposition. Solar observers, wishing to chart sun-spots, will find the "Disques Moreux," figured on p. 67, a useful adjunct to their outfit. The climatology of 1908 is reviewed, and at the end of the volume there are some useful instructions on the use of instruments for people commencing astronomical observation.

NO. 2097, VOL. 82]

\section{PRIZE AWARDS OF THE PARIS ACADEMY} OF SCIENCES.

$A^{\mathrm{T}}$ the annual public meeting of the Academy of $A$ Sciences, the president, M. Ch. Bouchard, delivered the annual address, dealing with the population question in France, and announced that the prizes for the year Igeg had been awarded as follows :-

Geometry.-The Francour prize to Émile Lemoine, for the whole of his works; the Bordin prize to G. Bagnera and Michele de Franchis, for their memoir on the number $\rho$ of M. Picard for hyperelliptic surfaces.

Mechanics.-A Montyon prize to M. Lecornu, for his book on applied dynamics; the Poncelet prize to $M$. de Sparre, for the whole of his works; the Boileau prize to M. Boulanger, for his treatise on hydraulics. No satisfactory memoirs having been received on the subject proposed for the Vaillant prize, this has been postponed until I9II.

Navigation.-The Prix Extraordinaire de la Marine divided between M. Marbec, for his memoir on the theory of the equilibrium of an elastic plate submitted to a uniform pressure; M. Doyère, for his work on submarines; M. L. J. H. Lecoq, for work on the stability of submarines ; MM. Victor Colin and Jeance, for their work on wireless telephony; M. Tissot, for work on wireless telegraphy; and M. E. Fromaget, for his river survey work in eastern French Africa. The Plumey prize between M. Routin, for his work on the regulation of electrogenic groups, and M. Henry Caralp, for his book on boilers and engines in warships.

Astronomy.-The Lalande prize to M. Borrelly, for his work as a whole; the Valz prize to $M$. de la BaumePluvinel, for his work on solar eclipses and the constitution of comets; the G. de Pontécoulant prize to Prof. E. W. Brown, of Yale, for his work on the theory of the moon. The Pierre Guzman prize was not awarded, and the Damoiseau prize postponed until 19II, no memoirs having been received on the subject proposed.

Geography.-The Tchihatchef prize was not awarded, but M. Henry de Bouillane de Lacoste receives a very honourable mention (2000 francs); the Gay prize to M. L. Joubin, for his researches on the distribution of marine plants in the Roscoff region.

Physics.-The Hébert prize to M. Paul Janet, for his book on general electrotechnics; the Hughes prize to $M$. Meslin, for his researches in physical optics, magnetooptics, and physical astronomy; the Gaston Planté prize to M. Jean Perrin, for his researches on the kathode rays and on the Brownian movement; the La Caze prize to M. Léon Teisserenc de Bort, for his contributions to meteorology and physics of the globe.

Chemistry. - The La Caze prize between M. G. Blanc, for his researches on the derivatives of camphor, and $M$. Marcel Guerbet, for his contributions to organic chemistry the Cahours prize between MM. Carré, Jolibois, and Brunel; Montyon prize (unhealthy trades) to MM. Emile Lefranc, Paul Letellier, and Maurice Perrot; the La Caze prize to M. Recoura, for his work on chromium compounds.

Mineralog $y$ and Geology.-The Grand prize of the physical sciences to M. A. Thévenin, for his memoir on the stages of evolution of the most ancient quadrupeds found in France; the Delesse prize to $\mathrm{M}$. Ph. Glangeaud, for his contributions to the geology of the Auvergne; the Victor Raulin prize (iog) to M. Léon Bertrand, for his contribution to the stratioraphical and tectonic history of the eastern and central Pyrenees, and (1909) to M. Ferdinand Gonnard, for his mineralogical researches; the Joseph Labbé prize to M. Georges Rolland, for his geological studies relating to the mine basin of Meurthe-et-Moselle.

Botany.--The Desmazières prize to M. l'Abbé Hue, for his researches on lichens: Montagne prizes to MM. H. and M. Peragallo, for their work on French marine diatoms, and M. Guilliermond, for his researches on the structure of the Cvanophycer and bacteria; the de Coincy prize to $M$. René Viguipr, for his work on the Araliaceæ; the Thore prize to M. Paul Bergon, for his researches on the structure and development of diatoms.

Anatomy and Zoology. - The Savigny prize to M. Robert du Buysson, for his entomological studies in Egypt; the 
da Gama Machado prize to MM. J. Pantel and R. de Sinéty, for their studies in spermatogenesis; the Cuvier prize to M. Charles Janet, for his anatomical and embryological researches on ants.

Medicine and Surgery.-Montyon prizes to MM. Neumann, Ch. Nicolle, Bergonié, and Tribondeau, mentions being accorded to MM. Moussu, H. Truc and P. Chavernac, $\mathrm{Ch}$. Porcher and $\mathrm{Ch}$. Hervieux, and a citation to MM. Henri Claude and Jean Camus. The Barbier prize between M. L. Launoy, for his researches on the conditions of activity of glandular cells, and M. J. Lesage, for his experimental studies on maté (Yerba maté). The Breant prize was not claimed, but from the interest of the fund a prize of 4000 francs was awarded to W. M. Haffkine, for his work on vaccination against cholera and plague, and a mention of 1000 francs to M. Louis Rénon, for his memoir on the practical treatment of pulmonary tuberculosis; the Godard prize to M. A. Pousson, for his work on the surgery of nephritis, and a very honourable mention to M. J. L. Chirié, for his studies on arterial hypertension; the Baron-Larrey prize to $M$. Niclot, for his researches on the relations between the numbers of Anopheles and cases of malaria in the Oran district, and a very honourable mention to MM. Dupard and Lepourcelet, for their contribution to the study of meat in the army; the Bellion prize to $M$. Ch. Nicolas, for his work on public and private hygiene in the Loyalty Islands; the Mège prize (interest) to M. S. J. Metalnikoff, for his researches on Galleria mellonella; the Parkin prize to M. Ad. Cartaz, for his therapeutical studies on carbon dioxide as applied to diseases of the nose and throat.

Physiology.-Montyon prizes to $M$. Charles Dhéré, for his spectrographic researches on the absorption of the ultra-violet rays by albumenoids, proteids, and their derivatives, and to M. E. Pozerski, for his contribution to the physiological study of papaine; the Philipeaux prize to MM. J. E. Abelous and E. Bardier, for their discovery of urohypertensine; the Lallemand prize between $M$. August Pettit and Gustave Roussy; the La Caze prize to M. C. Delezenne, for the whole of his researches in physiology. The Pourat prize was not awarded, and is postponed to $\mathrm{rg}$ II.

Statistics.-A Montyon prize to M. Louis de Goy, for his financial studies, M. Ausset receiving an honourable mention.

History of Science.-Binoux prizes to M. P. Duhem, for the whole of his works relating to the history of science, and M. J. B. de Toni, for his historical studies on the life and work of Italian philosophers of the fifteenth and sixteenth centuries.

General Prizes.-Berthelot medals to MM. G. Blanc, Marcel Guerbet, Jolibois, Brunel, Émile Lefranc, Paul Letellier, Maurice Perrot; the Gegner prize to M. J. H. Fabre; the Lannelongue prize to Mme. Cusco and Mme. de Nabias; the Trémont prize to $M$. Charles Fremont; the Wilde prize to $\mathrm{M}$. Joseph Vallot, for his work on Mt. Blanc; the Longchampt prize to M. Claudius Roux, for his work on the chlorosis of plants; the Saintour prize to MM. E. F. Gautier and R. Chudeau, for their scientific studies in the Sahara; the Jean Jacques Berger prize between MM. Bienvenue (3000 francs), Biette (1000 francs), Locherer (1000 francs), Thomas (rooo francs), Faillié ( 750 francs), Hervieu ( 750 francs), Chagnaud ( 750 francs), Daydé and Pillé ( $75^{\circ}$ francs), and Calmette (6000 francs). The Petit d'Ormoy prizes were not awarded. M. E. Mercadier receives the Pierson-Périn prize for his physical researches; M. Ritz and M. Lebeuf, 2000 francs each from the Leconte fund; M. Vaucheret, the prize founded by the Marquise de Laplace; and MM. Vaucheret, Hentschel, Messiah, and Courtaigne the prize founded by M. Felix Rivot.

The Bonaparte Fund.-The committee proposes the following grants from this fund for the year I909:-M. Cayeux, 4000 francs, to enable him to follow up in the United States his researches on oolitic iron-ore deposits, already commenced in France; M. Chevalier, 400o francs, to assist his explorations in tropical Africa: M. Pérez, 4000 francs, to assist in the publication of a memoir entitled "Recherches histologiques sur les Métamorphoses des Muscides"; M. Houard, 3000 francs, to enable him to travel in Corsica, Algeria, and Tumis for the purpose of collecting material; M. Berget, 2000 francs, for the NO. 2097, VOL. 82] construction of a special form of pendulum for studying the variations of gravity; M. Bernard, 2000 francs, to assist him in his photometric studies of the variations of solar radiation; M. Blaringhem, 2000 francs, to enable him to continue his experimental researches on the variation of species; M. Estanave, 2000 francs, to permit him to continue his researches on stereoscopic vision, stereoradiography, and autostereoscopy; M. Mathias, 2000 francs, to enable him to continue his researches at the Leyden cryogenic laboratory on the rectilinear diameter of liquids and on the law of corresponding states at very low temperatures.

The academy, taking advantage of the freedom accorded it under the terms of the Petit d'Ormoy foundation, has decided this year not to give this prize in the usual form, but to strike medals commemorative of the progress made in flying. Gold medals have accordingly been awarded to Louis Bleriot, Commandant Bouttieaux, Captain Crocco, Henri Farman, Captain Ferber, Henri Juilliot, Charles de Lambert, Hubert Latham, Léon Levavasseur, Col. Charles Renard and Commandant Paul Renard (one medal), Alberto Santos-Dumont, Rodolphe Soreau, Edouard Turcouf and Henri Kapferer (one medal), Léon Teisserenc de Bort, Henry de La Vaulx, Gabriel Voisin, Commandant Jules Vover, Orville Wright, Wilbur Wright and Count de Zeppelin. Also silver-gilt medals to Gustave Hermite and Georges Besançon, Louis Breguet, Léon Delagrange, Robert Esnault-Pelterie, L. Marchis, Louis Pauthan, Henri Rougier, and Victor Tatin.

\section{CLIMATOLOGICAL REPORTS.}

$T^{H E}$ director of the meteorological observatory at Chemulpo has issued the results of the observations made at the Japanese meteorological stations in Korea for each of the months January-December, 1908. The instruments and the method of observation are the same as those at the meteorological stations in Japan, and the readings, taken six times a day, are expressed in metric and centigrade measures, with monthly means and extremes. These form an important contribution to the meteorology of the Far East; their value would be much enhanced by the addition of annual summaries.

The report on rainfall registration in Mysore for 1908 shows that, except in the Shimoga (north-west) district, the amount was deficient in all parts of that important province, reaching 43 per cent. in Kolar (east). The deficiency of the fall during both monsoons was detrimental to the cultivation of ragi, which is the staple dry crop of the province. The tables for monthly, seasonal, and yearly periods have been carefully prepared by $\mathrm{Mr}$. Iyengar, as before, with diagrams and maps showing (I) the annual rainfall for 1908 , and (2) the average for $1870-1908$. The mean amount for the whole province in I908 was 29.94 inches, the average for the thirty-nine years' period being 36.79 inches. Among the heavy daily falls we note II.22 inches in Shimoga district, and 10.90 inches in Kadur district, both in the month of July.

An important memoir on the climate of Tripoli is published in the Annals of the Italian Central Meteorological Office (vol. xxx., part i.), containing the results of observations made during the years $1893^{-1907}$, at an observatcry established by the Italian Foreign Office and the Meteorological Service, and situated in lat. $32^{\circ} 54^{\prime} \mathrm{N}$., long. $13^{\circ} \mathrm{II}^{\prime} \mathrm{E}$. The mean monthly values of atmospheric pressure exhibit the greatest variability during the winter season, when the barometer is highest; the lowest readings occur during spring. The mean monthly temperatures do not show much variation from one year to another. The means of the daily maxima are $60.0^{\circ}$ in January and $86.2^{\circ}$ in August, and of the minima $46 \cdot 1^{\circ}$ in January and $72.9^{\circ}$ in August. The absolute maxima and minima were I09. $0^{\circ}$ in July and $34.5^{\circ}$ in January. The mean annual rainfall is 17.29 inches, most of which falls between October and February (14.85 inches); from June to August inclusive little or no rain falls. The memoir has been carefully prepared in considerable detail by Profs. Martinuzzi and Eredia, and is especially valuable, as comparatively little has hitherto been published on the climatology of that country. 